\title{
The Administration of Hajj in Brunei under the British Residency (1906 - 1954): A Historical Perspective
}

\author{
Bazilah Mobeen \\ Faculty of Arts and Social Sciences \\ University of Brunei Darussalam, Brunei Darussalam
}

DOI: https://doi.org/10.14710/jmsni.v5i1.8008

\begin{abstract}
This article explores the historical perspective of the Received: administration of hajj in Brunei under the British Residency from June 4, 2020 1906 until 1954. The pilgrimage reports were initially issued by the British and the British-Indian Officers. Malaysian pilgrims were previously misclassified as Javanese due to oversimplification of the officers in charge before the 1920s. Nevertheless, Bruneian pilgrims might interrelate with the same problem as they shared the same hajj routes. Eventually in the 1920s, the pilgrimage reports were mainly handled by the Malay Pilgrimage officer who was also known as the Malayan Pilgrimage Commissioner in

Accepted:

August 11, 2021

Revised:

June 12, 2021

${ }^{*}$ Corresponding Author: bazilah.mobeen@gmail.com 1948. The Malayan Pilgrimage Commissioner was responsible in handling the pilgrims from Brunei, Federation of Malaya, Sarawak, North Borneo, and Singapore during the pilgrimage season in Mecca at the time. Even though the Malayan Pilgrimage Commissioner eliminated the misclassification of Malaysian pilgrims, Bruneian pilgrims continued to be enumerated together with pilgrims from Malaysia under the rubric of 'Malay Pilgrims'. Primary and secondary research method are conducted for this article where various primary and secondary sources related to the administration of hajj in Brunei from 1906 until 1954 are used. This article discusses the roles and duties of the British Residents, local officers, Malayan Pilgrimage Commissioner, Medical Officers, and Sheikh Haji (Hajj Sheikh) in the hajj administration of the pilgrims from Brunei. This article further analyses British interests behind their involvements in the hajj administration.
\end{abstract}

Keywords: Hajj Administration; British Residency; Brunei; Malayan Pilgrimage Commissioner.

\section{Introduction}

It is acknowledged that the period of British Residency began in 1906 until 1959. However, this article deliberates the administration of hajj until 1954. As of July 1954, the administration of hajj in Brunei was handed to the locals under the Customs, Religious and Welfare Office (Kementerian Hal Ehwal Ugama 2012, 16). Even though there are several accounts of locals performing hajj before the period of British residency, the earliest record on the administration of hajj in Brunei from the British Resident Office record are only available from the year 1947. During the period of British Residency, the administration of hajj in Brunei was managed by the British Resident. The focal point for decision makings with regards to the administration of hajj for pilgrims from Brunei, Sarawak, North Borneo territories, Federation of Malaya, and Singapore was held in Kuala Lumpur and Singapore. At the time, the administration of hajj in the Bornean territories namely Brunei, Sarawak, and North Borneo was collectively administered together with the British Malaya, and Singapore. The Malay states only began to send Malay pilgrimage officer since the 1920s. By 1922, the general administration of hajj for the Malay states was handled by the Political Intelligence Bureau in Singapore until 1939 (Maslan 2014, 83-84). The duty of the Malay pilgrimage officer was previously held by the British and BritishIndian Officers. The Malayan Pilgrimage Commissioner officially handled the hajj pilgrims of 
Bornean territories in 1947 as the responsibility of handling the pilgrims from the Bornean territories in Mecca was previously held by the Sarawak Pilgrimage Officer (Brunei National Archives 1947c).

There are several authors who conducted the research on the history of hajj administration in Southeast Asia and British involvement in the hajj administration during the colonial era. Tagliacozzo's work entitled, 'The Longest Journey: Southeast Asians and the Pilgrimage to Mecca' and 'The Hajj by Sea', (Tagliacozzo 2013, 2016) examines the history, politics, and economy of hajj in Southeast Asia from the early times to the $21^{\text {st }}$ century. He provides a detailed description of hajj in Southeast Asia during the colonial era including the presentation of pilgrim's experience through tapes and memoirs. It describes the jurisdiction of British and Dutch Empire in Southeast Asia's hajj administration. In addition, his works also touches on the subject of routes and transportation for pilgrims in Southeast Asia from the early times to the $20^{\text {th }}$ century. Another work that delineates the history of the hajj administration in Southeast Asia is McDonnell's work entitled 'The Conduct of Hajj from Malaysia and Its Socio-Economic Impact on Malay Society: A Descriptive and Analytical Study 1860-1981' (McDonnell 1986). She assesses the conduct of hajj in Malaysia from the year 1860 to 1981 and provide a descriptive analysis of hajj management in Malaysia, with the addition of its socio-economic impact to the Malay community. A more specific view on British involvement in the hajj administration is found in Slight's work entitled 'The British Empire and the Hajj: 18651956' (Slight 2015) as it describes the involvements of British Empire in the hajj administration throughout history and their interest to further their imperial goals in the Hejaz. The same goes to Low's work entitled 'Empire and the Hajj: Pilgrims, Plagues, and Pan-Islam under British Surveillance, 1865-1908' (Low 2008) where it also analyses the administration of hajj under the domination of the colonial empires.

This article discusses the roles and duties of the British Residents and others namely the Malay pilgrimage officers, local officers, and medical officers, and the Sheikh Hajis in administering hajj of the Bruneian pilgrims. In addition to discovering how their tasks provided facilitation and convenience for the pilgrims. From this article it shows that, they did not provide proper or even enough facilitation and convenience for the Bruneian pilgrims at the time as there were lacking in terms of medical health care, shortage of staff, poor and lack of accommodation and transportation, and hajj fares inconsistency. However, they made the hajj administration in Brunei more organized than before as people in charge of specific tasks in managing hajj administration has emerged namely the British Resident, local officers, Malay pilgrimage officers, medical officers, and the Sheikh Hajis whereas, previously they were not handled as systematically. Furthermore, this article also discusses British interests with the hajj administration of their subjects during the colonial era.

\section{The Roles and Duties of British Resident in the Hajj Administration}

The British Resident Office was the main centre of the hajj administration in Brunei. The British Resident officially supervised almost all aspects of the hajj affairs in Brunei until July 1954. The main duty of the British Resident in the hajj administration was supervising and providing all the necessary hajj documents that were needed by local and the pilgrim-designates in order to pursue their hajj journey (Ibrahim 1966, 19; Brunei National Archives, n.d.). The British Resident Office provided registration documents that were needed for the pilgrimage which included issuing the pilgrims hajj passports to pilgrim-designates. After the registration and payments were made by the pilgrimsdesignates, the British Resident would issue the pilgrim hajj passports to them. The pilgrim's hajj passports were firstly introduced in 1924 by the Political Intelligence Bureau in accordance to the 'Pilgrim Pass Rule of 1926' (McDonnell 1986). In the Pilgrim's hajj passport, pilgrims must provide their photograph, name, residence, place of birth, race, name of their accompanying family members and their relationship, and their signature.

Before the pilgrims leave for Mecca, the British Resident would issue and publish public statements to notify and update the public which included the information on the hajj ship schedule and rules that needed to be followed by the pilgrim-designates during their hajj journey (McDonnell 1986). For example, the public statement for the 1951 hajj voyage announced that the ship carrying 
all pilgrims from Borneo would depart from Singapore on 12 August 1951. The statement further advises the pilgrim-designates to arrive in Singapore before the designated time. The pilgrimdesignates were also reminded to bring all important documents comprised of their hajj passports, and certificates of inoculation along with a $\$ 20$ fee in addition to a bank draft with a name issued to 'Finance Minister Saudi Arabia' for the hajj payment of $£ 48$ or $\$ 412$ per person, and another bank draft issued under their own name with the amount ranging from $£ 67.50$ or $\$ 579$ to not more than $£ 170$ or $\$ 1457$ per person (Brunei National Archives 1951b).

The public statement also provided more information on the rules and regulations of the bank drafts needed to be prepared specifically for children. The children under one year old was not entitled to have a bank draft since they did not have passports. While the children between one and five years old would be issued a bank draft of no more than $£ 33$ or $\$ 283$. Similarly, the children between six and 10 years old must prepare a bank draft of not less than $£ 33$ or $\$ 283$, but they were required to prepare another bank draft of $£ 24$ or $\$ 206$ for half of the payments needed by the Saudi Arabian Government (Brunei National Archives 1951b). The British Resident also provided leaflet instructions such as the instruction leaflets for the pilgrim-designates in 1949 highlighted the importance of pilgrim's hajj passport or a certificate of identity in the case of foreign pilgrims during their hajj journey. According to the leaflet, pilgrim-designates who were not in possession of the hajj passport or a certificate of identity would not be issued a pilgrim ticket. Pilgrim ship agent who issued tickets to those who were not in possession of the hajj passports or a certificate of identity must endorse the pilgrim's hajj passports, its numbers and date of issue. The pilgrim designates who did not have their hajj passports and a return passage ticket were not allowed to depart. Any death of pilgrims during the pilgrimage must be reported to the Agent of His Britannic Majesty (H.B.M. Agent) and Consul at Jeddah or to the Malay pilgrimage officer who would then issue the certificate of death to the next of kin. Pilgrims could ask for help from the H.B.M. Agent and Consul, or the Malay pilgrimage officer in solving the problems that might arise during the pilgrimage. Upon their return to Malaya, they must hand over their hajj passports to any police officer who must not be below the rank of sub-inspector (Brunei National Archives 1947d). The British Resident Office also provided the forms for the international certificates of vaccination against small-pox and international certificates for inoculation against cholera. Although the British Resident was given the full medical report by the Hajj Medical Mission, the resident was not in charge of the health affairs of the pilgrims during the hajj journey (Brunei National Archives 1947d).

For transportation, the British Resident would receive the reports on the hajj ship voyages by the Malay Welfare Officer through the Colonial Secretary in Singapore. In 1949, pilgrims from Brunei used Atreus ship from Singapore to Jeddah, Saudi Arabia (Brunei National Archives 1947a). In 1950s, almost all of the Malay pilgrims travelled together in one ship from Singapore to Jeddah. The total number of Malay pilgrims for the hajj voyage in 1951 was 5,809 pilgrims. The first batch of the Malay pilgrims left Penang on 27 May using the S.S. Tyndareus with 1,931 pilgrims altogether and they were accompanied by the Malayan Medical Mission and the Malayan pilgrimage commissioner. The Malay welfare officer accompanied the pilgrims during the second and third voyages (Brunei National Archives 1952c, 3). Before the next hajj season started, the ship schedule and the reports on the shipping of pilgrims to Jeddah prepared by J.F. Hannyngton, the Secretary to Member for Home Affairs was forwarded by the Colonial Secretary in Singapore to the British Resident. For instance, the ship schedule of Tyndareus Ship carrying pilgrims in 1952 outwards to Jeddah and homewards to Penang and Singapore (Brunei National Archives 1952d). The Tyndareus started its journey from Singapore on 14 May 1952 and ended its journey back to Singapore on 11 December 1952. In every outward voyage, the Tyndareus ship would stop by at Penang, and afterwards travelled to Aden and Kamaran in Yemen, before arriving in the Jeddah port in Saudi Arabia (Brunei National Archives 1952d). The pilgrims spent approximately six months abroad for their hajj journey. During the British Residency period, Bruneian pilgrims would leave Brunei Town to Labuan and boarded a ship that will transport them to Kuching, Singapore, and Penang where they met other pilgrims from Sarawak, North Borneo, Malaya and Singapore. Afterwards, they would board another ship where they stopped in several cities in Yemen namely Aden and Kamaran before they arrived at Jeddah. 
Table 1 shows the number of Malay Pilgrims divided by their nationality from 1946 until 1953. It was the first time that the pilgrimage record showed the nationalities of the Malay pilgrims. According to Table 1, there are no hajj pilgrims from the stated Malay countries from 1915 to 1918 and from 1941 to 1945 as there were an outbreak of the First World War and the Second World War respectively. There were also no hajj pilgrims from Brunei in 1946 and 1947 due to the devastating social economic impact of the Japanese Occupation that happened in Brunei from 1941 until 1945.

Table 1. Number of Malay Pilgrims Divided by Nationality 1946 - 1953

\begin{tabular}{lllllll}
\hline Year & Brunei & Sarawak & $\begin{array}{c}\text { North } \\
\text { Borneo }\end{array}$ & Malaya & Singapore & Total \\
\hline 1946 & - & - & - & 73 & 34 & 107 \\
1947 & - & 13 & 4 & 1636 & 255 & 1908 \\
1948 & 17 & 41 & - & 4278 & 288 & 4624 \\
1949 & 33 & 75 & 35 & 3035 & 75 & 3253 \\
1950 & 24 & 76 & 33 & not accessible & not accessible & 3835 \\
1951 & 70 & 179 & 45 & 5406 & 135 & 5835 \\
1952 & 81 & 283 & 111 & 5081 & 161 & 5717 \\
1953 & 65 & 199 & 32 & 5568 & 168 & 6032
\end{tabular}

Sources: Senarai Fail Pilgrimage/Pilgrimage Advisory Committee Meeting,

(Bandar Seri Begawan: Brunei National Archives).

The British Resident Office also managed the payment arrangement of the annual hajj expenses for Brunei. The accountant from the British Malaya and the Pilgrimage Control Officer would send all the details on the amount of the annual hajj expenses and expenditures to the British Resident to be reviewed before making payments. There was no information on the cost of hajj from 1897 to 1922 for the Malay pilgrims, but for the cost of hajj from Brunei it was not until the year 1948 that there was information on the cost of hajj (McDonnell 1986, 639). The pilgrimage expenditure was actually divided among the countries according to the number of pilgrims from each country. For instance, in 1951,70 pilgrims from Brunei amounted to a total of $\$ 625.96$ out of $\$ 52,178.25$ of the total pilgrimage expenditures of the year (Brunei National Archives 1952k). Table 2 shows the Brunei hajj expenditures from the year 1948 until 1953.

Table 2. Brunei Hajj Expenditures: 1948- 1953

\begin{tabular}{cllllll}
\hline & 1948 & 1949 & 1950 & 1951 & 1952 & 1953 \\
\hline $\begin{array}{c}\text { Brunei } \\
\text { pilgrims }\end{array}$ & 17 & 33 & 24 & 70 & 81 & 65 \\
$\begin{array}{c}\text { Total Malay } \\
\text { Pilgrims }\end{array}$ & 4624 & 3252 & 3835 & 5835 & 5717 & 6032 \\
$\begin{array}{c}\text { Total Hajj } \\
\text { Expenses }\end{array}$ & $\$ 29,852.92$ & $\$ 43,782.25$ & $\$ 22,395.29$ & $\$ 52,178.25$ & $\$ 75,047.31$ & $\$ 84348.01$ \\
$\begin{array}{c}\text { Brunei Hajj } \\
\text { Expenses }\end{array}$ & $\$ 109.75$ & $\$ 444.15$ & $\$ 140.15$ & $\$ 625.96$ & $\$ 1063.29$ & $\$ 908.92$ \\
\hline
\end{tabular}


Another role of the British Resident was to choose grantees for the complimentary hajj fares. In 1950, Sultan Omar Ali Saifuddien III ascended the throne and ruled Brunei until he abdicated in 1967. During his reign in 1953, he was asked by the British Resident to choose three civil servants with outstanding services to the state to be granted complimentary hajj fares (Brunei National Archives 1952e). The British Resident would also choose seven more civil servants to be granted the complimentary hajj fares. Despite given the task to choose, J. C. H. Barcroft who was the British Resident from 1951 until 1953 disapproved the choices made by the Sultan as two of his choices were not really serving for the state, but rather for the Sultan (Brunei National Archives 1953a). From that year onwards, the Sultan was allowed to select three people yearly with outstanding services to 'His Highness' and to 'the State' (Brunei National Archives 1953b). Giving advice to the Sultan in regards to the state's hajj affairs highlights an example of British involvement in the religious affairs that contradicted with the Supplementary Agreement 1906 where the resident should not advise the sultan on the religious matter of the country (Maxwell and Gibson 1988, 151).

Copies of the annual meetings of the annual Pilgrimage Advisory Committee minute would be sent to the British Resident for a review by the Office of Secretary for Native Affairs in Kuching, Sarawak. Concerns made by the locals would be referred to the Secretary for Native Affairs in Kuching, Sarawak to be presented and discussed during the meetings. Before 1952, the member of the pilgrimage advisory committee meeting was only among the officials from the Federation of Malaya and Singapore. Previously, the minutes of the meetings would be sent by mail to the Chief Secretary in Sarawak, the Chief Secretary in British North Borneo, and the British Resident in Brunei as a result, a proposal to appoint a representative from Borneo to be a member of the pilgrimage advisory committee was proposed in the fifth pilgrimage advisory committee meeting (Brunei National Archives 1951e). By 1952, Borneo was represented by D. C. White, Secretary for Native Affairs, and J. F. Hannyngton, Secretary to members of Home Affairs in the sixth pilgrimage advisory committee meeting (Brunei National Archives 1952i). Afterwards, the British Resident of Brunei was also present in the pilgrimage advisory committee to represent the Bornean pilgrims.

\section{The Roles and Duties of the Local Officers}

Local authorities from each district had a small part in the administration of hajj under the British Resident Office. Their main role was acting as intermediary between the locals and the British Resident Office. They were in charge of conveying the local's hajj administration enquiries to the British Resident, managing the hajj passports, and handling refunds for tickets and money. One of the duties of the Penghulu (Head of sub-district) was acting as a liaison between the locals and the British Resident. For instance, on 27 April 1948, the Penghulu of Kilanas sent a letter of inquiries to the British Resident, W. J. Peel about hajj expenses on behalf of the locals who wanted to perform the pilgrimage that year (Brunei National Archives 1948b). He was the British Resident in Brunei from 1946 to 1948. The British Resident forwarded the Penghulu's inquiry to the office of the Malay Pilgrimage Officer where it was stated that the pilgrim-designates should prepare approximately $\$ 1,700$ per person to enable them to stay in the Hejaz for four months (Brunei National Archives 1948a).

Other local officer in charge of handling the hajj affairs in Brunei was the District Officer. It was one of the duties of the District Officers to collect the hajj passport's fees, personal information, and photographs of the pilgrim designates in their districts. Afterwards, the District Officer would send it to the British Resident Office to be reviewed by the British Resident in order to issue their hajj passports. The District Officer would later send these hajj passports to the pilgrim-designates. For example, in 1949, the Belait District Officer was responsible to acquire passports, personal information, photographs, and $\$ 10$ hajj passport's fees from the pilgrims designates residing in the Belait District and forward it to the British Resident Office in Brunei Town (Brunei National Archives 1949). Another duty of the District Officer was also to handle the refund money of the deceased pilgrim's ticket to the next of kin. The copy of the receipts was then sent to the British Resident Office as requested by the British Resident. For instance, the Temburong District Officer 
received a balance of $\$ 150$ from the British Resident which was previously owned by Haji Jarudin bin Hakim who died in the pilgrimage in the year 1953. The Temburong District Officer was instructed to send the refund money to the next of kin, Mohamed Nasir bin Haji Jerudin, and expected to submit a receipt of acceptance to the British Resident Office (Brunei National Archives 1954).

\section{The Roles and Duties of the Malayan Officers}

While in Mecca, the Bruneian pilgrims were under the responsibility of the Malayan Pilgrimage Officer from Federation of Malaya who was also known as the Malayan Pilgrimage Commissioner. A Malay pilgrimage Officer only existed since the 1920s. According to the British Resident Office records, the discussions in the year 1947 were mainly focused on how to extend the hajj arrangements in Singapore and Malaya to meet the needs of pilgrims-designate in Sarawak, Brunei, and North Borneo. Sarawak and British North Borneo were both British colonies since 1946. It is stated that the duties of the Malayan Pilgrimage Commissioner were also to represent the pilgrimage officer for Brunei, Sarawak, and North Borneo (Brunei National Archives 1947b). The Malayan Pilgrimage Commissioner officially managed the hajj pilgrims of the Bornean territories namely Brunei, Sarawak, and North Borneo since 1947 as the responsibility of handling them was previously held by the Sarawak Pilgrimage Officer (Brunei National Archives 1947c). However, there were no information on what the Sarawak Pilgrimage Officer specifically manage. The Malayan Pilgrimage Commissioner also used the same kind of classification as the previous officers when recording their hajj reports (Brunei National Archives 1952c, 2).

Among the duties of Malayan Pilgrimage Officer was to attend to the needs of the pilgrims who came to the office such as handling the matters of missing persons, death of pilgrims, lost tickets, tickets refunds, pilgrim passports, and problems with bank drafts. For example, in 1951, some of the bank drafts used by the pilgrims could not be traded in the banks in Saudi Arabia. However, with the assistance of the Malayan Pilgrimage Commissioner, Haji Mohd. Ali bin Mohd. Rouse, the banks eventually paid the money back to the pilgrims (Brunei National Archives 1952c, 4). Another duty of the Malayan Pilgrimage Commissioner was to visit offices that is the British Embassy in Jeddah. He visited the Embassy in Jeddah in order to discuss pilgrim matters. For instance, the Malayan Pilgrimage Commissioner went to the British Embassy for advice on the bank drafts where the currency of the Pound Sterling could only be converted into Indian Rupee in Jeddah. The British Embassy suggested to the Malayan Pilgrimage Commissioner to consult the Manager of the British Bank in Iran who then promised to trade out gold sovereigns and Saudi Riyals (Brunei National Archives 1952c, 4).

He visited the pilgrim's ship agent in order to discuss pilgrims' tickets and travelling situations. In the pilgrimage of 1951, the Malayan Pilgrimage Commissioner expressed his gratitude to the Master, Captain Sanderson, the crew of the T.S.S. Tyndareaus, and the agents for the Blue Funnel Line in assisting him with eight pilgrims who lost their tickets and helped issued new tickets without charge (Brunei National Archives 1952c, 5). He also visited other Saudi Arabian Government offices for an update with the hajj administration and the annual report of the Saudi Arabian Government on the number of pilgrims. For example, the number of people congregated in 1951 at Arafah excluding 400,000 from Saudi Arabia was 100,578 people with a total of 5,767 under the label 'Malaya' (Brunei National Archives 1952c, 1 - 2). It was important for a Pilgrimage Officer to establish a good relation with the authorities in Mecca. For instance, the Embassy in Jeddah commended on the good relations between Haji Mohd. Ali Rouse, the Malayan Pilgrimage Commissioner in 1951 with all the Saudi Officials (Brunei National Archives 1951a). The duty of the Malayan Pilgrimage Commissioner was also handling the bank drafts of the pilgrims. In many cases the Malayan Pilgrimage Commissioner had to vouch for the pilgrims who had their bank drafts rejected by the banks in Saudi Arabia. Haji Mohd. Ali Rouse noted that several bank drafts from Brunei were refused by the banks in Saudi Arabia because the ink was faded. Consequently, he had to convince the bankers to give the pilgrims their money as the issue was only due to the ambiguity 
of the bank draft. In case there was a mistake in the bank drafts that were already paid to the pilgrims, the Malayan Pilgrimage Commissioner would pay to the bank instead (Brunei National Archives $1952 c, 4)$.

The Malayan Pilgrimage Commissioner was handling hajj refunds that is refunding the tickets of deceased pilgrims where the ticket would be returned to the British Embassy in the next hajj season. Apart from that, he was also in charge of refunding the lost tickets of the pilgrims where a proper investigation and verification whether the pilgrims did purchase the tickets would be conducted. If it was found that the pilgrims had purchase the ticket, the Malayan Pilgrimage Commissioner would ask the ship's agent to issue new tickets for the pilgrims. For example, in 1951 Haji Mohd. Ali Rouse, was able to refund new tickets for eight pilgrims who lost their tickets (Brunei National Archives 1952c, 4). In addition, the Malayan Pilgrimage Commissioner also handled money refunds. For instance, on 24 May 1952 the Pilgrimage Commissioner was responsible in managing the refund of pilgrimage dues when the Saudi Arabian Government issued a decree that ordered the cancellation of the Government Pilgrimage dues. The Malayan Pilgrimage Commissioner handled the refund of $£ 48$ fees to the first batch pilgrims who already paid to the Saudi Arabian Pilgrimage Officer (Brunei National Archives 1952c, 2). The Malayan Pilgrimage Commissioner also manage the issue of excess payments by carrying large amounts in their bank drafts. In order to avoid the excess payments, the Malayan Pilgrimage Commissioner provided a guide for the officials who were in charge for the preparation of drafts so that the problem could be avoided as the refund for the overpayment could take several years to obtain. In the guide of 1952, he stated that the pilgrims below the age of six were given free admittance, the fee for the pilgrims between six to ten years old was $£ 24$ per person, while the dues for pilgrims over ten years old was $£ 48$ per person (Brunei National Archives 1952c, 4). This were actually the exact amount to be brought during their pilgrimage.

The Malayan Pilgrimage Commissioner provide reports to the British Resident in Brunei regarding the activities and affairs of the Malay pilgrims throughout the pilgrimage as well. The reports would then be used in order to improve the hajj administration in Brunei in general. The report often includes responding to any inquiries related to hajj throughout the period of the British Residency System in Brunei. For instance, the notification made by the Malayan Pilgrimage Commissioner on the issue of excess payments and the solution given to avoid them helped the hajj administration in Brunei in tackling the problem of excess payments in order to avoid a long wait for the refund. The reports also include pilgrimage expenditures such as the pilgrimage expenditure incurred in 1952, where a total of \$75,047.31 were divided into five states namely Brunei, Sarawak, North Borneo, Singapore, and Federation of Malaya according to their number of pilgrims (Brunei National Archives 1953c). Letters, minutes of meetings, and memorandum regarding the hajj administration would be directed to selected offices namely, the British Resident in Brunei, the Colonial Secretary in Singapore, the Chief Secretary in Sarawak, the Chief Secretary in British North Borneo, the Secretary of Native Affairs in Sarawak, the Collector of Land Revenue in Penang, the Malayan Pilgrimage Commissioner, the Land Office in Penang, and the Social Welfare Department in Singapore (Brunei National Archives 1952a).

\section{The Roles and Duties of the Medical Officers}

Before the 1960s, the health of the Bruneian pilgrims in Mecca was under the responsibility of the Malayan Medical Mission or the Malayan Medical hajj team (Mail 2012, 100). The Malayan Medical Hajj team was firstly introduced in Mecca in 1948 (Maslan 2009; Maslan and Yaacob 2015, 381). The Malayan Medical team consisted of a team of medical experts. The first medical team on duty was led by Dr. Baboo and two other medical staffs. It was only in the 1960 s that Brunei started to send their own medical team thus ended the responsibility of the Malayan Medical Hajj team in attending the Bruneian pilgrims (Mail 2012, 100). Every hajj season, the Malayan Medical Hajj team would depart with the first hajj voyage as there were three voyages altogether along with their medical supplies and would only leave Mecca together with the last hajj voyage as their duty required them to work there for six months. For example, in the report by the Malayan Medical Mission in 1951 which 
departed on 27 May on the Tyndareus ship, they brought a case of medicine to Mecca. The first place they arrived at was in Jeddah and they stayed for five days before they travel to Mecca (Brunei National Archives 1951d, 1).

The Medical Mission was established at Gararag on a high ground from 1948 to 1950 . However, starting in 1951, the Medical Mission was located in the house of Shuib Ali. The Malayan Medical Clinic opened on 21 June 1951, the clinic shared the first floor with the Malayan Pilgrimage Commissioner Office. The second floor was occupied by the Malayan Pilgrimage Commissioner, the third floor was occupied by the doctors, and the fourth floor was the small room for other members of the Medical Mission. The sharing of space between the clinic and the Malayan Pilgrimage Commissioner Office on the first floor caused severe congestion as the patients, the pilgrims who were getting treatment and meeting the commissioner were crammed in one area. There was also no emergency ward, the place for dispensary is not suitable, the rooms were too small, there was no waiting room, the bed was not sufficient, and the location of first floor was not suitable for the elderly patients (Brunei National Archives 1951d, 2).

Among the duty of the Malayan Medical Mission was to send a full medical report to the British Resident in Brunei. The medical report consisted of the medical services, cases of infectious diseases, medical facilities, number of deaths, medical storages, visiting patients, recommendations, their voyage to Mecca, accommodation, transportation, name and number of personnel, and the weather in Mecca (Brunei National Archives 1952f, 1). The report of the Malayan Medical Mission to Mecca was used to assess the health situation of the pilgrims during their pilgrimage and helped to improve what was lacking through the reviews and recommendations. The Malayan Medical Mission was to provide medical care to the Malay pilgrims during their pilgrimage. Most of the medical cases treated by the Malayan Medical Mission were fevers, lung infections, and skin infections. In 1952, Dr. Haji Ahmad bin Alang Sidin, the Federation of Malaya's Director of Medical Services suggested that the medicines for influenza, diarrhea, and malaria should be provided in Penang before leaving to Mecca as the medicines and vaccinations stored in the Malayan Medical Clinic in Mecca for treating and fighting viral diseases were inadequate (Brunei National Archives 1952f, 1).

The duty of the Malayan Medical Mission was not only in the clinic, they also had to treat sick pilgrims outside their working area such as treating patients in Arafah and Mina, and treating patients who were too ill to go to the clinic in their room or camp (Brunei National Archives 1952f, 1). For example, in 1951, there were 34 new patients in Arafah, 61 new patients and four revisit patients in Mina, and a total of 64 patients for the domiciliary visits (Brunei National Archives 1952f, 2). The visits were sometime troublesome due to the lack of transport. In 1951, there was no transport available for the Malayan Medical Mission as their car was not working. Therefore, the visits were met using the Malayan Pilgrimage Commissioner's car or just walk to attend to the pilgrims who needed medical help (Brunei National Archives 1952f, 3).

\section{The Roles and Duties of the Sheikh Haji (Hajj Sheikh)}

The Sheikh Haji was the oldest method used by the locals to manage their hajj journey (Pelita Brunei 1984, 3). The Sheikh Haji acted as the pilgrim's broker, and also mutawwif (guide). The pilgrims were required to pay the Sheikh Haji through bank drafts as a method of payments (Mail 2012, 37 38). However, the payments demanded by the Sheikh Haji were normally inconsistent. For example, in 1952, the Sheikh Haji charged 224 Saudi Riyals for the first batch of pilgrims, 222 Saudi Riyals for the second batch, and $£ 23.50$ for the third batch. Normally, the pilgrim-designates identified the Sheikh Haji from people who previously performed hajj or the Sheikh Haji themselves through their advertisements. The nationalities of the Sheikh Haji were mainly comprised of Bruneians and Arabs. The Arab Sheikh Haji were mainly centred in Singapore and toured to other Malay states to find groups of pilgrim-designates to hire them during the pilgrimage season (Maslan 2014, 81). Out of the two nationalities, the locals preferred the service of the local Sheikh Haji than the Arab Sheikh Haji as it was easier to get their services than the Arabs. Among the roles and duties of the Sheikh Haji were to prepare all the necessary arrangements for pilgrims including preparing the documents 
required for hajj, accommodation, transportation, and provide hajj reports to the British Resident in Brunei and also to the Director of Political Intelligence Bureau in Singapore. However, locals still need to hire another Sheikh Haji in Singapore as their broker during their stay there.

In preparing the hajj documents, the Sheikh Haji would prepare hajj passports, bank drafts, and visa application. When the pilgrims arrived in Jeddah, the pilgrims must submit their hajj passports and bank drafts to be examined by the officials of the Saudi Arabian Government. Then, they were taken to an interrogation room called the Bab-ul-Soal room (the gate of questions room) to identify their Sheikh Haji in order for the officials to verify their affiliation. The Sheikh Haji and the pilgrims would stay in Jeddah for two nights in order for the Sheikh Haji to manage the pilgrim's hajj passports to make sure their passports were in order before applying their visas in Mecca (Maslan 2014, 81). During their stay, the Sheikh Haji would take the pilgrims for sightseeing including shopping, eating in the restaurants, and cash their bank drafts at the banks in Jeddah. In preparing for the accommodation, the Sheikh Haji was to arrange accommodation for the pilgrims while they were in Singapore, Jeddah, and Mecca. Most of the accommodation prepared for the pilgrims were not satisfactory as there were small, poorly ventilated, and unhygienic. In 1951, there were problems of overcrowding, as the accommodation in Singapore was small. There were no proper bins to dispose the litters, and no facility to hang the clothes that caused the littering of the rubbish all over places and clothes hanging over the sleeping areas (Brunei National Archives 1952j, 3). Before heading to Jeddah, the pilgrim designates had to stay in Singapore for approximately two weeks. When the inspection was carried out by the Federation Pilgrim Control Officer, Secretariat of Singapore, and Officials from the Singapore Pilgrimage Office on the pilgrim's accommodations, the Sheikh Haji were then requested to get an extra accommodation for the pilgrims. The situation was too bad, the Education Department of Singapore had to loan its unused school in Palembang Road to accommodate the pilgrims (Brunei National Archives 1951c, 1).

In Jeddah, before 1952, the Sheikh Haji provided their own houses for the pilgrims to stay in for approximately a week while they managed the pilgrim's hajj affairs namely managing hajj passports, bank drafts, and visas application (Brunei National Archives 1952c, 2). The pilgrims were no longer staying in the houses of their Sheikh Haji by 1952, but at the pilgrim camps for two nights. The pilgrim camps could accommodate around 3,000 to 4,000 pilgrims, but most of the time, the number of pilgrims exceeded up to 200,000 pilgrims which forced some of the pilgrims to sleep by the roadside. Despite the effort made by the Saudi Arabian Government to add more pilgrim camps, the issue of overcrowding was still not resolved. This also happened in Mecca where the rooms were old, small, unhygienic, and poorly ventilated (Brunei National Archives 1951b). In Mecca, the Sheikh Haji also provided meals for the pilgrims as the expenditure for the meals came under the tariff dues (Brunei National Archives 1952i). In Jeddah, the Sheikh Haji also had to prepare transport to take the pilgrims and their luggage to Mecca and Medina. The transportation was in the form of buses, cars, vans and taxis (Brunei National Archives 1952c, 2). However, in 1951, the pilgrims were not allowed to ride other vehicles including those that were provided by the Sheikh Haji except the transportation that was provided by the Saudi Arabian Government. The transportation fee from Mecca to Medina was 112.50 Saudi Riyals per person, and the fee from Jeddah to Mecca was 22.50 Saudi Riyals per person which was the same amount as the fee for the one-way journey from Mecca to Mina, and to Arafah (Brunei National Archives 1952c, 3). After the end of their hajj, the Sheikh Haji had to provide the hajj report for the British Resident in Brunei, and the Director of Political Intelligence Bureau in Singapore (Maslan 2014, 81). The report consisted of information concerning the pilgrim's affairs during the pilgrimage such as the report of missing pilgrims, and the health situation of the pilgrims including illness and childbirth. For example, a report sent by Sheikh Haji Ibrahim on the missing of Pengiran Untong bin Pengiran Jaya in Mina near Mecca where he had to assemble a search party to search for Pengiran Untong at the pilgrim camps, Mina Hospital, and camps for lost person. He had to file a missing person's report at the Mina Police Station and requested their help. Three days later, he went to Mecca informing the authorities and continued searching but failed (Brunei National Archives 1952b). 


\section{British Interests in the Hajj Administration}

Since the 18th century, British oversees the hajj administration in some parts of Southeast Asia (Tagliacozzo 2016, 127-128). Most British policies often starts with a trade interest as an intention to control territories. British interest in the hajj affairs was initially intended to be a trade interest in the Middle East as its Middle East policies were mainly to preserve British accessibility towards the trade routes between Europe and India (McDonnell 1986, 91). Then, ever since the invasion of Egypt by Napoleon in 1798, Britain became more attentive in taking over the territories of the Ottoman Empire that eventually led to British military intervention in 1882. British authorized a commercial and consular representative in Jeddah in the mid-19th century and by 1878 , British has established a full-status consular office in Jeddah. Its establishment was to oversee the commercial and pilgrim's activities, and to prevent their European rivals from attaining any territorial or commercial supremacy in the Hejaz (Bidwell 1971, 3). According to Slight, British was anxious about their empire's prestige in the Islamic world. They employed a significant number of Muslim intermediaries in the hajj administration who extensively shaped imperial policies (Slight, 2015).

British interest to control the administration of hajj was also meant as a political surveillance to combat radicalism. Pilgrims from different British colonies had the opportunity to meet one another during hajj where some pilgrims might spread anti-British sentiments that can spark radical movements in their home country (Tagliacozzo 2016, 128). Especially after several Intellectuals from Al-Azhar University in Egypt with anti-British sentiments fled to Mecca to following the British military occupation in 1882 (McDonnell 1986, 40). They fear that hajj would become an outlet for Muslim radicalism and anti-British sentiment. For example, they were concerned with the rise of Indian pilgrims to Mecca where they can be exposed to anti-colonialism from external influences from Saudi Arabia and contributed to the ongoing Mutiny in India at the time (Low 2008).

Another major interest to control the hajj administration was to monitor the sanitary issues that began in 1892 during an outbreak of a cholera epidemic in the Middle East. It led to the arrangements of various sanitary conferences. Unfortunately, many of the conferences failed to implement the measures systematically. It was only in 1897, during a conference held in Venice, Italy that it effectively utilized the measures against viral diseases that ranges from cholera infection to the plague virus (McDonnell 1986, 49-50). As an effort to contain any viral diseases, a quarantine station was built near Jeddah at the Kamaran Island. However, Snouck Hurgronje criticized that the quarantine island was unequipped and ineffective to stop any type of viral diseases. For instance, Hurgronje addressed the limited supply of water in the quarantine island where he witnessed the archipelago pilgrims had succumbed to drink the water that they bathed in (Tagliacozzo 2009, 142). The returning Malay pilgrims who were infected with infectious disease would then be quarantined at the St John's Island that was located few kilometres to the south of the main island of Singapore. At the time, it was the world's biggest quarantine station to screen Asian immigrants and no longer serve as a quarantine station since the 1950s (Cliff and Smallman-Raynor 2013, 75).

Although not a major interest, ending slavery was also a part of British interest in the hajj administration. In 1838, the British Slavery Abolition Act of 1833 was in full effect in outlawing slave trade and slavery in its empire (Gleissner 2010, 106). There was a concern of slavery activities that alarmed the British in the 19th century. There was an increase of slave market activities during hajj as it became a popular form of charity for the pilgrims to free the slaves they purchased. There was also an illegal slave trading activity that kidnapped foreign pilgrims to be imported as slaves (Hurgronje and Monahan 1931, 13-20). However, the British involvement in the administration of hajj were rarely due to the concerns towards the pilgrims and their hajj. It was not until the mid1870 s that they began to genuinely show interest in the pilgrim's health conditions and welfare where they became more attentive in the hajj regulations. Captain George Beyts, a British trader and diplomat, was the first to describe the pilgrim's harsh conditions during hajj and initiate the change to be more conscientious in regulating the hajj administration (McDonnell 1986, 92). 


\section{Conclusion}

The administration of hajj under the British Resident in Brunei was not as voluminous as the hajj administration in Singapore and Malaya. New regulations set were to ensure the ease and safety of the pilgrims in Brunei. The main factors for British intervention in the hajj administration were their trade interest in the Middle East, to fulfil their imperialist ambition, to avoid anti-colonial subversion and sanitation purposes in restraining viral diseases. Regardless of their intentions, the massive task of managing the hajj administration to be more organized in fact required their expertise in matters of formalities and bureaucratic processes which the locals could not provide at the time. The sharing of information on the developments of hajj affairs and cooperation between the British Resident, local officers, Malayan Pilgrimage Commissioner, Medical Officers, and the Sheikh Hajis was an effort to link the administration of hajj in the British colonies and their protectorate in Southeast Asia. Although it was lacking when compared to the present-day hajj administration, the cooperation provided more convenience and facilities to the people in Brunei at the time which made it easier for the British Resident to gradually hand over the authority of administering the hajj administration in Brunei to the locals in 1954.

\section{References}

BA/12104/1978 BRO/159/1947. 1947a. A letter from the Colonial Secretary in Singapore to the Chief Secretaries in Kuching and Jesselton, Pilgrimage to Mecca. Bandar Seri Begawan: Brunei National Archives.

BA/12104/1978, BRO/159/1947. 1947b. A letter from Lieutenant Colonel J. D. Dalley, the Director of Malayan Security Service to the Chief Secretary for the Government in Kuching Sarawak, 17 April 1947. Bandar Seri Begawan: Brunei National Archives.

BA/12104/1978, BRO/159/1947. 1947c. A letter providing the duties and functions of the Malay Pilgrimage Officer for Malaya from the Director of Malayan Security Service, Lt. Col. J. D. Dalley to the Chief Secretary in Brunei. Bandar Seri Begawan: Brunei National Archives.

BA/12104/1978, BRO/159/1947. 1947d. Sets of forms issued by the British Resident. Bandar Seri Begawan: Brunei National Archives.

BA/12104/1978, BRO/159/1947. 1948a. A letter from the Malay Pilgrimage Officer in Singapore to the Secretary of the British Resident in Brunei, 19 May 1948. Bandar Seri Begawan: Brunei National Archives.

BA/12104/1978, BRO/159/1947. 1948b. A letter from the sub-district Chief of Kilanas to the British Resident, 27 April 1948. Bandar Seri Begawan: Brunei National Archives.

BA/12104/1978, BRO/159/1947. 1949. A memorandum from the Belait District Officer to the Secretary of the British Resident in Brunei, 12 April 1949. Bandar Seri Begawan: Brunei National Archives.

BA/12443/1978 BRO/172/1951. 1951a. A Report from British Embassy in Jeddah, on disembarkation of the second shipload of pilgrims by E.F.G Maynard, 25 July 1951. Bandar Seri Begawan: Brunei National Archives.

BA/12443/1978 BRO/172/1951. 1951b. Public Statement for the 1951 hajj voyage issued by the British Resident's Office, 18 May 1951. Bandar Seri Begawan: Brunei National Archives.

BA/12443/1978 BRO/172/1951. 1951c. The Inspection of Pilgrim Broker Lodging Houses in 1951 by Tuan Haji Abu Bakar Federation Pilgrim Control officer and Che Rahman Abu of Singapore Pilgrimage Office. Bandar Seri Begawan: Brunei National Archives.

BA/12443/1978 BRO/172/1951. 1951d. The Report of the Pilgrim Medical Mission to Mecca 1951 by Malayan Medical Officer. Bandar Seri Begawan: Brunei National Archives.

BA/12443/1978 BRO/172/1951. 1952a. Mecca Pilgrimage 1952 Third Voyage of the "Tyndareus", 17 June 1952. Bandar Seri Begawan: Brunei National Archives. 
BA/12443/1978 BRO/172/1951. 1952c. The Report on the Pilgrimage to Mecca for 1951 by Malayan Pilgrimage Commissioner, Haji Mohd. Ali bin Mohd. Rouse. 8 February 1952. Bandar Seri Begawan: Brunei National Archives.

BA/12443/1978 BRO/172/1951. 1952d. The schedule of the Tyndareus Voyages in 1952. Bandar Seri Begawan: Brunei National Archives.

BA/12443/1978, BRO/172/1951. 1952b. Hajj Report by Sheikh Haji Ibrahim bin Sheikh Abdul Rahman to the Secretary to the British Resident in Brunei dated 24 May 1952. Bandar Seri Begawan: Brunei National Archives.

BA/12674/1978 BRO/627/1951 PT.I. 1951e. Minute of the 5th meeting of the pilgrimage advisory committee in Singapore, 12 November 1951. Bandar Seri Begawan: Brunei National Archives.

BA/12674/1978 BRO/627/1951 PT.I. 1952i. Minute of the 6th meeting of the pilgrimage advisory committee in Kuala Lumpur, 18 March 1952. Bandar Seri Begawan: Brunei National Archives.

BA/12674/1978 BRO/627/1951. 1952j. Report on the pilgrimage to Mecca for 1952 by Malayan Pilgrimage Commissioner, Mokhtar Yassin. Bandar Seri Begawan: Brunei National Archives.

BA/12674/1978, Bro/627/1951 PT.I. 1954. A letter from the Secretary to British Resident to the Temburong District Officer, 16 December 1954. Bandar Seri Begawan: Brunei National Archives.

BA/12675/1978 BRO/627/1951/PT.II. 1952e. An announcement from British Resident J. C. H. Barcroft, Pilgrimage to Mecca, 14th February 1952. Bandar Seri Begawan: Brunei National Archives.

BA/126751 1978 BRO/627/1951/PT.II. 1952f. Malayan Medical Mission 1952 by Director of Medical Services, Dr. Haji Ahmad bin Alang Sidin, 20 November 1952. Bandar Seri Begawan: Brunei National Archives.

BA/12678/1978 BRO/633/1951. 1953a. A letter from the British Resident to the Sultan, 9 January 1953. Bandar Seri Begawan: Brunei National Archives.

BA/12678/1978 BRO/633/1951. 1953b. A letter from the Private Secretary of His Highness the Sultan of Brunei to the British Resident, 'Pilgrims Selected by His Highness the Sultan', 15 January 1953. Bandar Seri Begawan: Brunei National Archives.

BA/1983.1.0493, BRO/298/52. 1952k. A letter from J. F. Hannyngton to the British Resident in Brunei, 8 September 1952. Bandar Seri Begawan: Brunei National Archives.

BA/1983.1.0493, BRO/298/52. 1953c. Pilgrimage Expenditure 1952, 16 April 1953. Bandar Seri Begawan: Brunei National Archives.

Bidwell, R. 1971. The affairs of Arabia, 1905-1906: Foreign office confidential print. London: Cass.

Cliff, A. and M. Smallman-Raynor. 2013. Oxford Textbook of infectious disease control: A geographical analysis from medieval quarantine to global eradication. Oxford: Oxford University Press.

Gleissner, J. D. 2010. Prison and Slavery - A Surprising Comparison. Colorado: Outskirts Press.

Hurgronje, C. S. and J. H. Monahan. 1931. Mekka in the latter part of the 19th century. Leyden: Late E. J. Brill.

Kementerian Hal Ehwal Ugama Brunei Darussalam. 2012. 50 Tahun Dalam Ristaan: Perkhidmatan Hal Ehwal Ugama (1959-2009). Bandar Seri Begawan: Kementerian Hal Ehwal Ugama.

Low, M. C. 2008. "Empire and the Hajj: Pilgrims, Plagues, and Pan-Islam under British Surveillance, 1865-1908”. Int. J. Middle East Stud. 40, 269-290. Printed in the United States of America. DOI: $10.1017 /$ S0020743808080549.

Mail, H.A.A.H. 2012. "Sejarah Ibadat Haji Negara Brunei Darussalam (1950-1983): Masyarakat Islam dan Peranan Kerajaan," in Kemerdekaan 25 Tahun: Kumpulan Artikel Sejarah Memperingati 25 Tahun Kemerdekaan Negara Brunei Darussalam. Bandar Seri Begawan: Yayasan Sultan Haji Hassanal Bolkiah \& Persatuan Sejarah Brunei.

Maslan, A. 2009. Dari Tabung Buluh Ke Tabung Haji: Sejarah Pengerjaan Haji Orang Melayu, 1860-1984. PhD diss., University of Malaya.

Maslan, A. 2014. "Hajj and the Malayan Experience, 1860s-1941". Kemanusiaan: The Asian Journal of Humanities. Kuala Lumpur: Universiti Sains Malaysia. 
Maslan, A. and N. H. Yaacob. 2015. "The Malays Hajj: Health and Sanitation Issues before World War II," in Proceedings of ADVED15 International Conference on Advances in Education and Social Sciences, Istanbul.

Maxwell, W. G. and Gibson, W. S. 1988. Treaties and engagements affecting the Malay States and Borneo. London: J. Truscott \& Son Limited.

McDonnell, M. B. 1986. "The Conduct of Hajj from Malaysia and Its Socio-Economic Impact on Malay Society: A Descriptive and Analytical Study 1860-1981”. PhD diss., Columbia University. Pelita Brunei, 1984, July 11.

Senarai Fail Pilgrimage/Pilgrimage Advisory Committee Meeting. Bandar Seri Begawan: Brunei National Archives.

Slight, J. 2015. The British Empire and the Hajj: 1865-1956. Cambridge: Harvard University Press.

Tagliacozzo, E. 2009. Southeast Asia and the Middle East: Islam, movement, and the Longue durée. Stanford: Stanford University Press.

Tagliacozzo, E. 2016. The Hajj by Sea. In E. Tagliacozzo \& S. M. Toorawa (Eds.), The Hajj: Pilgrimage in Islam. New York: Cambridge University Press.

Tagliocozzo, E. 2013. The longest journey: Southeast Asians and the pilgrimage to Mecca. New York: Oxford University Press.

Tinggal, A. I. 1966. "Pegawai Urusan Haji," in Buku Kenang-Kenangan Istiadat Pembukaan Rasmi Bangunan Baharu Jabatan Hal Ehwal Ugama 1 september 1966. Bandar Seri Begawan: Jabatan Hal Ehwal Ugama. 